\title{
Horsegram Induced Gynecomastia
}

\author{
Sindhu Sree Rallapalli, Sunanda Tirupati, Vijaya Sarathi* and Dileep Kumar \\ Department of Endocrinology, Narayana Medical College, India
}

*Corresponding author: Vijaya Sarathi, Associate Professor, Department of Endocrinology, Narayana Medical College, Nellore, India

Submission: 監 April 04, 2018; Published: 眥 April 27, 2018

\begin{abstract}
Gynecomastia is benign enlargement of male breast. It is caused by high estrogen to androgen ratio, attributable to various causes of estrogen excess or androgen deficiency. Herewith we report a case of gynecomastia in a middle aged man due to excess consumption of horse-gram, containing flavonoids which are estrogenic compounds. Gynecomastia regressed gradually after stopping horse-gram consumption, without any other medical or surgical interventions.
\end{abstract}

Keywords: Gynecomastia; Horse-gram; Flavonoids

\section{Introduction}

Gynecomastia develops due to high estrogen or low androgen levels/activity [1]. Exposure to exogenous estrogens is one of the causes, which includes excess consumption of phytoestrogens [2]. Isoflavones and flavonoids are phytoestrogens that can cause gynecomastia when ingested in high quantities. Case reports of gynecomastia due to Soy isoflavones [3]; lavender and tea tree oils [4] have been reported. Here we report a case of horse gram flavonoid induced gynecomastia.

\section{Case Report}

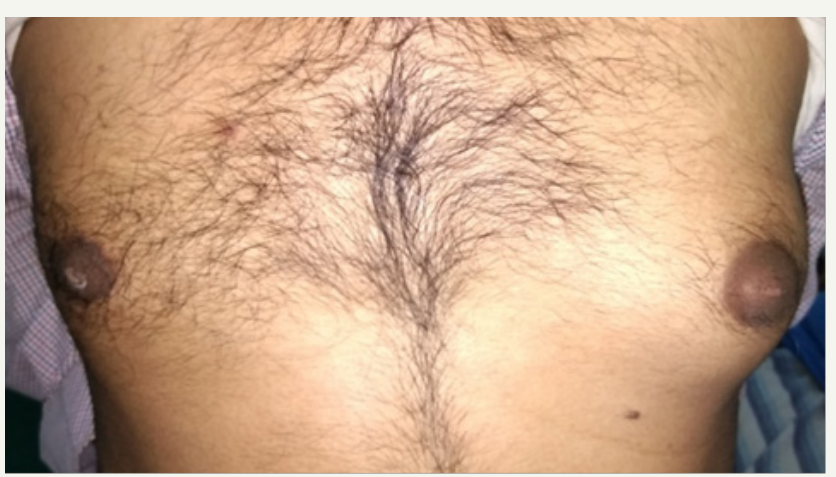

Figure 1: Bilateral gynecomastia (Left $>$ right).

A 41 years old gentleman presented to Endocrinology outpatient services with complaints of pain and enlargement of both breasts for the past 2 months. There was no history suggestive of primary or secondary hypogonadism, relevant systemic illnesses or consumption of medications/supplements. There wasn't any history of regression of secondary sexual characters or reduced sexual desire or function. He was consuming about 100g of boiled horse gram per day for the past 4 months, for weight loss and diabetes prevention, which he started on his own after obtaining the information from internet. He temporally related onset of gynecomastia to horse gram intake with onset of gynecomastia after 4 weeks of starting horse gram consumption. Patient was obese (BMI: $28.2 \mathrm{~kg} / \mathrm{m}^{2}$ ) and breast examination revealed tender, asymmetric bilateral gynecomastia (larger on left side), with no discharge on expression (Figure 1). External genitalia and sexual maturity rating (SMR: P5, stretched penile length: $12 \mathrm{~cm}$, testes volume: 20cc bilateral) were appropriate for age. Hormonal evaluation was normal except for mild elevation of serum estradiol (Table 1).

Table 1: Hormonal evaluation for gynecomastia.

\begin{tabular}{|c|c|}
\hline Investigation & Observed Value \\
\hline Serum Free thyroxine & $0.94 \mathrm{ng} / \mathrm{dl}$ \\
\hline Serum thyroid stimulating hormone & $1.16 \mu \mathrm{IU} / \mathrm{ml}$ \\
\hline Serum estradiol & $78 \mathrm{pg} / \mathrm{ml}$ \\
\hline Serum follicle stimulating hormone & $7.16 \mathrm{mIU} / \mathrm{ml}$ \\
\hline Testosterone & $5.16 \mathrm{ng} / \mathrm{ml}$ \\
\hline Beta human chorionic gonadotropin & $0.22 \mathrm{mIU} / \mathrm{ml}$ \\
\hline Dehydroepiandrosterone & $117.9 \mu \mathrm{d} / \mathrm{dl}$ \\
\hline
\end{tabular}

Ultrasound of breasts revealed glandular tissue of $4.8 \mathrm{~cm} \mathrm{x}$ $3.2 \mathrm{~cm}$ and $1.2 \mathrm{~cm} \times 1.8 \mathrm{~cm}$ in left and right breasts respectively, and was of diffuse glandular type of gynecomastia. No radiological evidence of breast tumour was found. As there wasn't any other etiological history except for horse gram intake, we advised him to stop its consumption; suggested lifestyle modification for weight loss and diabetes prevention. On follow up there was reduction in glandular tissue size which gradually regressed over 6 months, without any additional specific medical or surgical interventions. 


\section{Discussion}

Gynecomastia is benign enlargement of male breast caused by proliferation of glandular tissue [5,6]. It can be defined as the presence of $>2 \mathrm{~cm}$ of palpable, firm, subareolar gland and ductal breast tissue [7]. Prevalence is about $30-70 \%$ in adult men [8]. Estrogens stimulate breast tissue proliferation, whereas androgens inhibit this process [1]. It is believed that most cases of gynecomastia are caused by an imbalance of these two influences, where estrogen-induced stimulation dominates $[9,10]$.

Causes of estrogen excess can be exogenous or endogenous. Exogenous causes include exposure in form of estrogen containing nutritional supplements or medications, skin contact with estrogen containing cream or cosmetics, occupational exposure or excessive consumption of phytoestrogens [11]. Phytoestrogens are substances of plant origin that are structurally and functionally analogous to the estrogen, 17 $\beta$-estradiol (E2) [12-14]. They include various groups of compounds like isoflavonoids, lignans, flavonoids and polyphenols, which in turn have multiple subgroups [15]. Isoflavones and lignans are abundant in soy products and flax respectively, [16] with soy containing more than about 100 phytoestrogens [15].

Horse-gram (Macrotyloma uniflorum) is a minor legume used as a pulse crop in India with good nutritional quality. Horse-gram contains many phytoestrogens of flavonols group (flavonoids) such as quercetin, kaempferol, myricetin, daidzein, and genistein [17]. Seed concentrations of myricetin, quercetin, and kaempferol

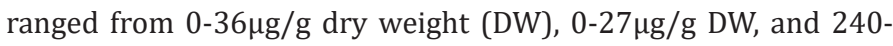
$316 \mu \mathrm{g} / \mathrm{g}$ DW, respectively [18].

Case reports of gynecomastia due to phytoestrogens have been described for soy compounds [3]; lavender and tea tree oils [4]. To the best of our knowledge, we report the first case of horse gram induced gynecomastia. Management of gynecomastia is directed at correction of underlying cause. Discontinuation of the offending compound causes resolution of gynecomastia, as observed in our case, thus potentially avoiding any medical or surgical therapies and associated social and financial burden over patients.

\section{References}

1. Dimitrikakis C, Zhou J, Bondy CA (2002) Androgens and mammary growth and neoplasia. Fertil Steril 77(Suppl 4): S26-S33.

2. Dickson G (2012) Gynecomastia. Am Fam Physician 85(7): 716-722.

3. Martinez J, Lewi J (2008) An Unusual Case of Gynecomastia Associated with Soy Product Consumption. Endocr Pract 14(4): 415-418.

4. Henley DV, Lipson N, Korach KS, Bloch CA (2007) Prepubertal gynecomastia linked to lavender and tea tree oils. N Engl J Med 356(5): 479-485.

5. Braunstein GD (2007) Clinical practice. Gynecomastia. N Engl J Med 357(12): 1229-1237.

6. Narula HS, Carslon HE (2014) Gynaecomastia-pathophysiology, diagnosis and treatment. Nat Rev Endocrinol 10(11): 684-698.

7. Niewoehner CB, Schorer AE (2008) Gynaecomastia and breast cancer in men. BMJ 336(7646): 709-713.

8. Carlson HE (2011) Approach to gynecomastia. J Clin Endocrinol Metab 96(1): 15-21.

9. Mathur R, Braunstein GD (1997) Gynecomastia: pathomechanisms and treatment strategies. Horm Res 48(3): 95-102.

10. Johnson RE, Murad MH (2009) Gynecomastia-pathophysiology, evaluation and management. Mayo Clin Proc 84(11): 1010-1015.

11. Matsumoto AM, Bremner WJ (2016) Testicular disorders. In: Melmed S, Polonsky KS, Larsen PR, Krokenberg HM (Eds.), Williams textbook of Endocrinology (13 ${ }^{\text {th }}$ edn), Elseiver, Canada, pp. 1389-1391.

12. Sreedhar RP, Jhansi RD (2011) Phytoestrogens: risks and benefits. Internat Journal of Pharmaceutical Sciences Review and Research 10(1): 121-126.

13. Christopher RC, Serge N (2009) Soy-Phytoestrogens and metabolism: A review. Mol Cell Endocrinol 304(1-2): 30-42.

14. Jargin SV (2014) Soy and phytoestrogens: possible side effects. Ger Med Sci 12(1-5): 1612-3174.

15. Patisaul HB, Jefferson W (2010) The pros and cons of phytoestrogens. Front Neuroendocrinol 31(4): 400-419.

16. Stark A, Madar Z (2002) Phytoestrogens: a review of recent findings. J Pediatr Endocrinol Metab 15(5): 561-572.

17. Prasad SK, Singh MK (2015) Horse gram-an underutilized nutraceutical pulse crop: a review. J Food Sci Technol 52(5): 2489-2499.

18. Morris JB, Li Wang M, Grusak MA, Tonnis B (2013) Fatty Acid, Flavonol, and Mineral Composition Variability among Seven Macrotyloma uniflorum (Lam.) Verdc. Accessions. Agriculture 3(1): 157-169.
Creative Commons Attribution 4.0 International License

For possible submissions Click Here

\section{Submit Article}

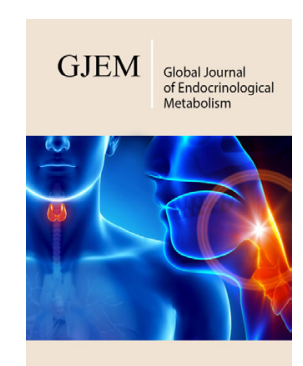

Global Journal of Endocrinological Metabolism

\section{Benefits of Publishing with us}

- High-level peer review and editorial services

- Freely accessible online immediately upon publication

- Authors retain the copyright to their work

- Licensing it under a Creative Commons license

- Visibility through different online platforms 